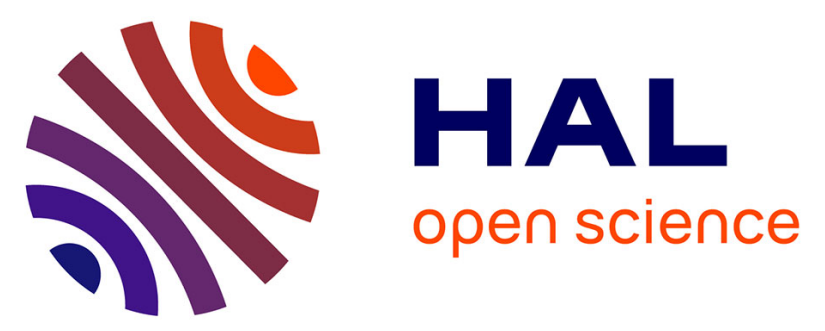

\title{
Use of MCDM and AI Techniques for Mechanization of In-Service Inspection Planning Process
}

\author{
A. B. Seneviratne, R. Chandima Ratnayake
}

\section{To cite this version:}

A. B. Seneviratne, R. Chandima Ratnayake. Use of MCDM and AI Techniques for Mechanization of In-Service Inspection Planning Process. IFIP International Conference on Advances in Production Management Systems (APMS), Sep 2014, Ajaccio, France. pp.264-271, 10.1007/978-3-662-447338_33. hal-01387191

\author{
HAL Id: hal-01387191 \\ https://hal.inria.fr/hal-01387191
}

Submitted on 25 Oct 2016

HAL is a multi-disciplinary open access archive for the deposit and dissemination of scientific research documents, whether they are published or not. The documents may come from teaching and research institutions in France or abroad, or from public or private research centers.
L'archive ouverte pluridisciplinaire HAL, est destinée au dépôt et à la diffusion de documents scientifiques de niveau recherche, publiés ou non, émanant des établissements d'enseignement et de recherche français ou étrangers, des laboratoires publics ou privés. 


\title{
Use of MCDM \& AI Techniques for Mechanization of In- Service Inspection Planning Process
}

\author{
A.M.N.D.B. Seneviratne and R.M. Chandima Ratnayake \\ University of Stavanger, Stavanger, Norway \\ chandima.ratnayake@uis.no, dammika.seneviratne@uis.no
}

\begin{abstract}
The in-service inspection planning process for topside piping equipment of aging oil and gas $(\mathrm{O} \& \mathrm{G})$ production and process facilities (P\&PFs) involves personnel with different kinds of expertise, experience, and knowledge as well as a vast amount of data and information. To simplify the inspection planning process and increase the quality of an inspection program, various industrial organizations as well as researchers have been developing numerous techniques in an isolated fashion to address the challenges pertaining to different activities involved in the inspection planning process. In order to mechanize the overall inspection process, suitable techniques need to be identified for the different activities carried out in a generic inspection planning process. This manuscript discusses the potential use of multi-criteria decision analysis (MCDM) and artificial intelligence (AI) techniques. It also provides evidence about the suitability of AI techniques in relation to fuzzy logic and artificial neural networks for the mechanization of the inspection planning process in a dynamic manner.
\end{abstract}

Keywords: In-service inspection planning, · AI techniques, · MCDM techniques, $\cdot$ Inspection programs, $\cdot$ Aging O\&G P\&PFs

\section{Introduction}

In offshore $\mathrm{P} \& \mathrm{PFs}$, the topside piping equipment plays a vital role in the production of hydrocarbons $(\mathrm{O} \& \mathrm{G})$. In this process, performing equipment maintenance at a level anticipated to comply with the standards and guidelines imposed by regulatory authorities (i.e. Petroleum Safety Authority (PSA), Norway) is a mandatory task for the aging O\&G P\&PFs operating in the North Sea. Therefore, the owner/operator companies of the P\&PFs conduct inspections to identify the equipment's fitness for service and the level of required maintenance and modifications (Ratnayake, 2012a). In this context, the in-service inspection planning process, which consists of a series of subprocesses, for instance, preparation of inspection programs, carrying out inspections at plant level, evaluating inspection results and updating the risk level of equipment, feedback for operation and maintenance and evaluation of resource allocation for the next inspection cycle, is of major significance.

Researchers have identified the importance of inspection planning in various industrial settings, and reliability-based and risk-based approaches were developed from 1963 onwards, gradually establishing risk-based inspection (RBI) concepts for the planning of inspections over the last 25-30 years (Ratnayake et al., 2011; Straub \& Faber, 2006). The application of RBI planning has been limited in the past due to the significant numerical effort required by these methods. The MCDM methods, such as 
the analytic network process (ANP), and the analytic hierarchy process (AHP) developed by Satty (1980), were applied by many researchers in different levels of the inspection planning process. Ratnayake (2012a, 2012b, 2013) and Ratnayake \& Markeset (2010) used AHP in planning inspections for topside mechanical equipment. The views of the industry's professionals were considered in developing these AHP models to recommend critical thickness measurement locations (TMLs) (Ratnayake, 2012a, 2012b). The models were based on prioritizing the critical TMLs and optimising the cost for the inspections. Dey (2004) also used the AHP in hydrocarbon pipeline inspection planning, which was illustrated by case studies. The AI techniquebased models were also developed to identify critical TMLs, considering the degradation mechanisms. The techniques, for instance fuzzy logic and artificial neural network (ANN), are used by Nesic et al. (2009), Singh and Markeset (2009), Zio (2012) in developing the models. Most of these models are based on empirical methods, in which planning personnel use these models together with their expertise for the planning purposes. The models which developed utilizing AI techniques are more able to incorporate expertise than the empirical models.

This manuscript discusses the advantages and disadvantages of the MCDM and AI approaches in the inspection planning process. The goal of this paper is to identify the sub-processes in the inspection planning process where it is possible to use the AI techniques for the mechanisation of the inspection planning process.

\section{Background}

The inspection planning work process is defined in several standards, for instance DNV RP G101 (2010) and API RP 581 (2008), and illustrates the sub-processes and flow of sub-processes. A generic inspection planning work process consisting of subprocesses that have been employed in the industry is illustrated in Fig. 1.

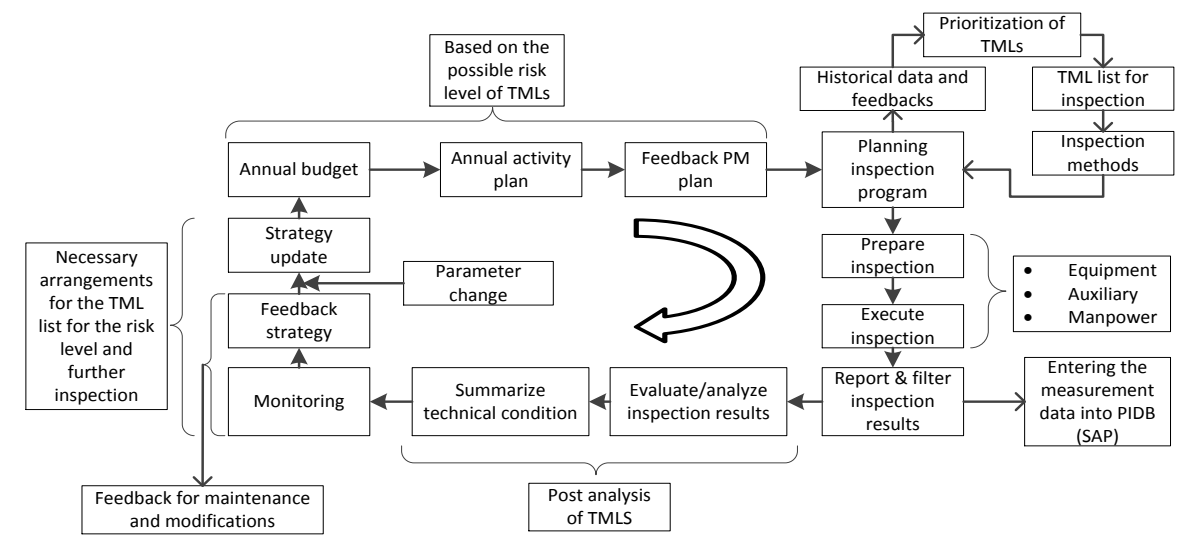

Fig. 1. Inspection planning work process

The main part of the inspection planning work process is the preparation of the inspection program. In planning inspection programs, the recommendation of critical TMLs for inspection is a primary task. A huge amount of data is gathered, and various techniques are used to identify TMLs by prioritization of criticality. In P\&PFs, the 
topside piping equipment inspection planning personnel's primary concern is corrosion and erosion trends. However, there are other degradation trends, for instance, fatigue degradation, crack propagation due to fatigue, stress-induced cracking, slug effects, flow turbulence effects, stress generation, thermal effects, etc. In general, chemical and mechanical corrosion have been taken into consideration (i.e. $\mathrm{CO}_{2}$ corrosion, $\mathrm{H}_{2} \mathrm{~S}$ corrosion, microbially-induced corrosion and sand erosion) during inspection planning. NORSOK M-506 (2005) and DNV RP O501 (2007) are examples of the models developed in standards to assist the inspection planning. The prioritization of identified critical TMLs is based on the thresholds provided by the governing documents, for instance plant strategy, RBI guidelines, piping standards (e.g. ASME B31.3), etc.

In executing inspections, resource allocation is another major part of the planning process. The TMLs' accessibility, methods for inspection, manpower and working hours needed to be calculated. The feedback process performs by comparing the current measurements and historical data to identify the current risk level of TMLs. Furthermore, the annual inspection budget, the annual activity plan and the feedback PM plan are assigned according to the feedback provided by the risk level of the TMLs. Therefore, the inspection planning sub-processes consist of data analysis, forecasting, optimizing and prioritizing. Currently this is performed by using basic calculations and primary software tools.

\section{$3 \quad$ Static and Dynamic Modelling for Inspection Planning}

The models developed in the condition based maintenance and monitoring paradigm, in particular to identify the inspection intervals and the prioritization of the inspections can be divided into static and dynamic models (Wang, 2003). Static models are driven by the fixed condition monitoring interval data, while dynamic models are driven by both fixed condition monitoring interval data and real-time condition monitoring data. Therefore, the dynamic model overrides the static model with real-time condition monitoring data, which keeps the equipment under close attention before an appropriate mitigation action takes place when it reaches a critical level (Wang, 2003). The currently developed static and dynamic models are less likely to connect to the real-time condition monitoring data (Jardine et al., 2006). However, the aging P\&PFs are constantly affected by the changing production and process conditions where the deterioration and degradation trends are dramatically changing over time. Therefore, the dynamic behaviour of the models which can be connected to the condition monitoring data will be useful for the aging P\&PFs to monitor the critical equipment regularly.

\section{The Decision Support Modules in Inspection Planning}

Different decision support modules (DSM) are developed based on the static and dynamic models to support the decision-making process of the sub-processes in inspection planning. DSMs are developed in an isolated fashion to address the different scenarios, such as the identification of different degradation trends for TMLs, the prioritization of TMLs, inspection methods, etc. However, a number of researchers have observed the difficulty in making proper decisions on the above analysing process and have suggested different approaches. The main model development is fo- 
cused on degradation monitoring followed by the identification of critical TMLs. The techniques, for instance AHP, ANP, outranking, fuzzy logic, artificial neural networks and genetic algorithms, are used in developing the DSMs.

The main contribution of the DSM in inspection planning is through degradation models. Ratnayake \& Markeset (2010) and Singh \& Markeset (2009) have reviewed the degradations and degradation models for $O \& G$ topside piping and hydrocarbon transportation pipelines. The $\mathrm{O} \& \mathrm{G}$ piping equipment is frequently subject to different degradation mechanisms, internally and externally. A number of manuscripts address specific types of corrosion behaviour: Ramsamooj and Shugar (2001) offer a detailed description of corrosion and fatigue modelling in unfavourable conditions; NORSOK M-506 (2005), Singh \& Markeset (2009) and Valor et al. (2010) address $\mathrm{CO}_{2}$-driven corrosion and the problems of pitting corrosion; Walton et al. (1996) deal with the problems of modelling marine corrosion damage, and DNV RP O501 (2007) illustrates the erosion behaviour of the equipment subjected to produced sand. A large amount of degradation modelling causes the problem to converge into one variable situation, by treating individual items of equipment independently. For large systems, such as those found in the O\&G industry, this is a practical assumption that allows the modeller to handle potentially intractable modelling problems. However, this is not usually a realistic assumption since the systems are undergoing different degradation mechanisms in different locations at different times. Therefore, the application of different degradation models (i.e. based on different degradation mechanisms) in one system will enable the identification of different degradation tends in the TMLs. The results from the different models can be used for cumulative prioritization to identify the most critical TMLs in a system.

\section{$5 \quad$ Use of MCDM and AI Methods in Inspection Planning}

The MCDM and AI techniques are used in static as well as dynamic modelling of the stages of the inspection planning process. The main functions of the exploited models are optimization, forecasting and prioritization. In MCDM, there are two different approaches for problem solving. The first is to evaluate problems which consist of a known number of alternatives in the solution domain. The second approach is where the number of alternatives for the problem is unknown. However, in this situation, the problem is solved by mathematical modelling to identify the solution (Triantaphyllou, 2000). Therefore, in the inspection planning process of $O \& G$ topside piping equipment, the alternatives are limited and the first approach in MCDM is used by many researchers.

Outranking methods, ANP and AHP are the three most frequently used MCDM techniques for prioritization (Bozbura and Beskese, 2007). The outranking methods determine which alternatives are being preferred to the others by systematically comparing each criterion instead of building complex utility functions (Brans et al., 2005). In AHP, pair-wise comparisons are made in between elements at each level of the hierarchy by means of a nominal scale to establish a comparison matrix. The eigenvector of the matrix is derived as the weights' vector of elements at the hierarchy. Finally, overall priority can be obtained by synthesizing local and global weights. The fuzzy version of AHP is preferred in the prioritization of problems for the following reasons: no measurement scale needs to be explicitly defined for each criteri- 
on/attribute in pair-wise comparison; representation of uncertainties such as vagueness; non-specificity and discord can be incorporated in the models (Klir and Yuan, 1995). However, there are limitations in using fuzzy-AHP, and these are some of the problems: a high number of computational requirements; only triangular membership functions can be used; difficulties with criteria and attribute addition and deletion and the number of pair-wise comparisons are increased with the number of criteria (Buyukozkan et al., 2004).

In recent years artificial intelligence techniques have also been used successfully in condition based maintenance planning. The earliest works made use of expert systems (Medsker, 1994); then came a number of studies using ANN (Caputo \& Pelagagge, 2002). Jang (1993) proposed the adaptive network-based fuzzy inference system (ANFIS), a hybrid learning algorithm extensively used in forecasting problems. The ANN model is also used with a back propagation algorithm for predicting failure rates (Al-Garni et al., 2006). Ciarapica and Giacchetta (2006) experimentally used ANN and neuro-fuzzy systems to forecast activities in the rotating machinery preventive maintenance cycles. Genetic algorithms are used in optimizing the maintenance schedule tasks in production environments by Cavory et al. (2001). These are also used by Sortrakul et al. (2005) to solve an integrated optimization model for production scheduling and preventive maintenance planning. More recently, several works have employed fuzzy logic systems in the identification of critical TMLs (Ratnayake, 2014a, 2014b; Seneviratne \& Ratnayake, 2013). However, the neuro-fuzzy approach integrates the neural networks and fuzzy logic to create powerful expert decision systems. Many authors have proposed various neuro-fuzzy models and complex training algorithms in inspection and maintenance planning (Zhang et al., 2004). Table 1 illustrates the usage of different methods for inspection planning process modelling in various industries with their advantages and disadvantages.

Table 1. Comparison of usage of MCDM/AI techniques in inspection planning

\begin{tabular}{|c|c|c|c|}
\hline Method & $\begin{array}{l}\text { Usage in inspection planning process } \\
\text { modelling }\end{array}$ & Advantages & Disadvantages \\
\hline $\begin{array}{l}\text { MCDM } \\
\text { methods } \\
\text { (Brans and } \\
\text { Mareschal, } \\
\text { 2005) }\end{array}$ & $\begin{array}{l}\text { Extensively used in inspection planning. } \\
\text { Static modelling behaviour due to the fixed } \\
\text { designed methods by designer. } \\
\text { Decision selection is from fixed alternative } \\
\text { domain. }\end{array}$ & $\begin{array}{l}\text { Easy interpretation of the } \\
\text { criteria and alternatives. } \\
\text { Easy for designing the models. } \\
\text { Flexibility in defining the } \\
\text { threshold limits. }\end{array}$ & $\begin{array}{l}\text { Static behaviour of the models. } \\
\text { Reflects the designer's perspec- } \\
\text { tives. } \\
\text { Fixed boundaries in generating } \\
\text { decisions. }\end{array}$ \\
\hline $\begin{array}{l}\text { Fuzzy logic } \\
\text { (Buyukoz- } \\
\text { kan et al., } \\
2004 \text { ) }\end{array}$ & $\begin{array}{l}\text { Relatively well used in the inspection } \\
\text { planning. } \\
\text { Represents the process uncertainty pa- } \\
\text { rameters. } \\
\text { Modelling is static. However, by incorpo- } \\
\text { rating other Al techniques, dynamic be- } \\
\text { haviour can be obtained. } \\
\text { Utilizes vagueness and impression of } \\
\text { parameters to design noise-tolerant mod- } \\
\text { els. } \\
\text { Rule base inferencing. }\end{array}$ & $\begin{array}{l}\text { Interpretation of expert } \\
\text { knowledge, intuition and expe- } \\
\text { rience. } \\
\text { Interprets the vague, noise and } \\
\text { imprecise data and infor- } \\
\text { mation. } \\
\text { Rule base is used to mimic } \\
\text { human-like reasoning by using } \\
\text { suitable inferencing methods. }\end{array}$ & $\begin{array}{l}\text { More toward static behaviour in } \\
\text { the modelling. } \\
\text { Limitations in interpreting hu- } \\
\text { man-like reasoning behaviour. } \\
\text { Inability of self-learning capabili- } \\
\text { ties. }\end{array}$ \\
\hline $\begin{array}{l}\text { Artificial } \\
\text { neural } \\
\text { network } \\
\text { (Zhang et } \\
\text { al., 2004; }\end{array}$ & $\begin{array}{l}\text { Relatively well used in inspection planning. } \\
\text { Dynamic behaviour is observed in the } \\
\text { neural network models. } \\
\text { Equipped with the self-learning abilities to } \\
\text { adapt the problem-solving capabilities. }\end{array}$ & $\begin{array}{l}\text { Dynamic and good in model- } \\
\text { ling nonlinear and unstable } \\
\text { processes. } \\
\text { Trained for complex input } \\
\text { output modelling. }\end{array}$ & $\begin{array}{l}\text { Selection and designing of ANN } \\
\text { for solving a problem situation is } \\
\text { complex. } \\
\text { Identification of proper network } \\
\text { design needs extensive effort }\end{array}$ \\
\hline
\end{tabular}




\begin{tabular}{|c|c|c|c|}
\hline $\begin{array}{l}\text { Caputo \& } \\
\text { Pelagagge, } \\
\text { 2002) }\end{array}$ & & $\begin{array}{l}\text { Self-learning abilities (adap- } \\
\text { tively). } \\
\text { Different types of architecture } \\
\text { for different levels and different } \\
\text { types of complex problems. }\end{array}$ & $\begin{array}{l}\text { and research. } \\
\text { Training and validation of the } \\
\text { designed ANN requires large } \\
\text { amount of data. }\end{array}$ \\
\hline $\begin{array}{l}\text { Genetic } \\
\text { algorithms } \\
\text { (Cavory et } \\
\text { al., 2001) }\end{array}$ & $\begin{array}{l}\text { Limited use in inspection planning. } \\
\text { Shows more static behaviour in the model- } \\
\text { ling. } \\
\text { Dynamic behaviour can be adapted using } \\
\text { fitness function. }\end{array}$ & $\begin{array}{l}\text { Easy representation of criteria } \\
\text { and fast generation of outputs. } \\
\text { Simple designing of a model. }\end{array}$ & $\begin{array}{l}\text { Depends on the designers } \\
\text { perspectives. } \\
\text { No flexibility for imprecise data. } \\
\text { Rigid in model construction. }\end{array}$ \\
\hline $\begin{array}{l}\text { Bayesian } \\
\text { networks } \\
\text { (Lee et al., } \\
\text { 2014) }\end{array}$ & $\begin{array}{l}\text { Extensively used in inspection planning. } \\
\text { Static in behaviour since the model uses } \\
\text { the statistical methods (probability). }\end{array}$ & $\begin{array}{l}\text { Able to represent the historical } \\
\text { behaviour. } \\
\text { Easy for designing models and } \\
\text { generating desired output. } \\
\text { Reduction of number of pa- } \\
\text { rameters by conditional proba- } \\
\text { bility distribution. }\end{array}$ & $\begin{array}{l}\text { Static in behaviour and relies on } \\
\text { the designer's intuition and } \\
\text { knowledge. } \\
\text { Limited representation of the } \\
\text { new data in the system. } \\
\text { Less adaptability to the system } \\
\text { behaviour. }\end{array}$ \\
\hline $\begin{array}{l}\text { Petri nets } \\
\text { (Ratnayake, } \\
\text { 2012a) }\end{array}$ & $\begin{array}{l}\text { Limited use in inspection planning } \\
\text { Static behaviour (less adaptability). } \\
\text { Dynamically used, but cannot change the } \\
\text { parameters. }\end{array}$ & Easy to model. & $\begin{array}{l}\text { Limited alternatives in the mod- } \\
\text { elling process. } \\
\text { Needs extensive understanding } \\
\text { of the process for modelling. }\end{array}$ \\
\hline $\begin{array}{l}\text { Hidden } \\
\text { Markov } \\
\text { model (Lee } \\
\text { et al., 2014) }\end{array}$ & $\begin{array}{l}\text { Limited use in inspection planning. } \\
\text { In between static and dynamic (has some } \\
\text { level of adaptability). } \\
\text { Less dynamic in nature. } \\
\text { Dynamic as a hybrid model with unknown } \\
\text { state space parameters. }\end{array}$ & $\begin{array}{l}\text { Can be used for fault and } \\
\text { degradation diagnosis on non } \\
\text { stationary signals and dynamic } \\
\text { systems. } \\
\text { Appropriate for multi failure } \\
\text { mode. }\end{array}$ & $\begin{array}{l}\text { Not appropriate when the failure } \\
\text { state is observable. } \\
\text { Large amount of data is needed } \\
\text { for accurate modelling. }\end{array}$ \\
\hline
\end{tabular}

Although different models have been developed using different techniques, full mechanization of the inspection planning process has not yet been achieved. Researchers address the mechanization of some of the sub-processes illustrated in Fig. 1. To achieve total mechanization, as short-term goals, correct techniques for modelling the sub-processes needed to be identified. As middle-term goals, the knowledge bases for the models needed to be created. For long-term goals, full mechanization can be achieved by the integration of models, developed knowledge bases and the connection of condition monitoring sensors to the models.

\section{Discussions and Conclusions}

The planning process consists of several stages with different levels of data analysis. In this analysis the experience, knowledge and intuition of the field experts is extensively used. In the mechanization of the inspection planning process, prioritization techniques which can incorporate human-like abilities need to be used. The techniques, for instance fuzzy logic and ANN, demonstrate human-like reasoning abilities. However, referring to the advantages and disadvantages illustrated in Table 1, individual AI techniques show only a limited number of reasoning behaviours. Therefore, the use of multiple AI techniques in a model as hybrid AI techniques will enable human-like reasoning abilities to be embedded into the DSMs.

In the O\&G P\&PFs, the product and process condition variations cause the arbitrary degradation trends of aged equipment which are reaching critical levels. However, the financial productivity is less in aged P\&PFs. Therefore, owner/operator companies face difficulties in performing inspections regularly to monitor the critical equipment. Hence, the dynamic modelling approach is necessary for the aged O\&G 
P\&PF inspection planning, where the condition monitoring data can be linked to the DSMs to identify the critical TMLs in a dynamic manner.

\section{Acknowledgements}

The authors would like to thank Roy Martin Zydeman and the in-service inspection planning team in Aker Solutions Offshore Partner, Norway, for their support in this research study.

\section{References}

API RP 581 Risk Based Inspection Technology. 2nd ed. American Petroleum Institute (2008)

Al-Garni, A.Z., Jamal, A., Ahmad, A.M., Al-Garni, A.M., Tozan, M.: (2006). Neural NetworkBased Failure Rate Prediction for De Havilland Dash-8 Ttires. Eng. Appl. Artif. Intel. 19, 681-691 (2008)

Bozbura, F.T., Beskese, A.: Prioritization of Organizational Capital Measurement Indicators Using Fuzzy AHP. Int. J. Approx. Reason. 44, 124-147 (2007)

Brans, J.P., Mareschal, B.: PROMETHEE Methods. In: Multiple Criteria Decision Analysis: State of the Art Surveys, pp. 163-186. Springer, New York (2005)

Buyukozkan, G., Kahraman, C., Ruan, D.: A Fuzzy Multicriteria Decision Approach for Software Development Strategy Selection. Int. J. Gen. Syst. 33 (April-June), 259-280 (2004)

Caputo, A.C., Pelagagge, P.M.: An Inverse Approach for Piping Network Monitoring. J. Loss Prevent. Proc. 15, 497-505 (2002)

Cavory, G., Dupas, R. \& Goncalves, G.: A Genetic Approach to the Scheduling of Preventive Maintenance Tasks on a Single Product Manufacturing Production Line. Int. J. Prod. Econ. 74, 135-146 (2011)

Ciarapica, F.E., Giacchetta, G.: Managing the Condition-Based Maintenance of a CombinedCycle Power Plant: An Approach Using Soft Computing Techniques. J. Loss Prevent. Proc. 19, 316-325 (2006)

DNV RP G101 : Risk Based Inspection of Offshore Topside Static Mechanical Equipment. Det Norske Veritas (DNV), Norway (2010)

DNV RP O501 Recommended Practice DNV RP O501: Erosive Wear in Piping Systems. Det Norske Veritas (DNV), Norway (2007)

Dey, P.K.: Decision Support System for Inspection and Maintenance: A Case Study of Oil Pipelines. IEEE T. Eng. Manage. 51, 47-56 (2004)

Jardine, A.K.S., Lin, D., Banjevic, D.: A Review on Machinery Diagnostics and Prognostics Implementing Condition-Based Maintenance. Mech. Syst. Signal Pr. 20, 1483-1510 (2006)

Jang, J.S.: ANFIS: Adaptive-Network-Based Fuzzy Inference System. IEEE T. Syst.Man Cyb. 23, 665-685 (1993)

Klir, G.J., Yuan, B.: Fuzzy Sets and Fuzzy Logic: Theory and Applications. Prentice Hall International, Upper Saddle River, New Jersey (1995)

Lee, J., Wu, F., Zhao, W., Ghaffari, M., Liao, L., Siegel, D.: Prognostics and Health Management Design for Rotary Machinery Systems - Reviews, Methodology and Applications. Mech. Syst. Signal Pr. 42, 314-334 (2014)

Medsker, L.: Design and Development of Hybrid Neural Network and Expert Systems. In: IEEE International Conference on Neural Networks-Conference Proceedings, vol. 3, pp. 1470-1474 (1994)

Nesic, S., Li, H., Huang, J., Sormaz, D.: An Open Source Mechanistic Model for CO2 / H2S Corrosion of Carbon Steel. NACE International, Corrosion 2009, Paper No. 09572 (2009)

NORSOK M-506 NORSOK Standard M-506: CO2 Corrosion Rate Calculation Model. Standards Norway, Lysaker, Norway (2005)

Ramsamooj, D.V., Shugar, T.A.: Modeling of Corrosion Fatigue in Metals in an Aggressive Environment. Int. J. Fatigue. 23, Supplement 1, 301-309 (2001) 
Ratnayake, R.M.C.: Challenges in Inspection Planning For Maintenance Of Static Mechanical Equipment On Ageing Oil And Gas Production Plants: The State Of The Art. In: Proceedings of the ASME 31st International Conference on Ocean, Off-shore and Arctic Engineering, paper no. OMAE2011-49050 (2012a)

Ratnayake, R.M.C.: A Decision Model for Executing Plant Strategy: Maintaining the Technical Integrity of Petroleum Flowlines. Int. J. Decision Sciences, Risk and Management (IDJRSM) 4(1/2), 1-24 (2012b)

Ratnayake, R.M.C.: Utilization of Piping Inspection Data for Continuous Improvement: A Methodology to Visualize Coverage and Finding Rates. In: Proceedings of the ASME 32nd International Conference on Ocean, Offshore and Arctic Engineering, paper no. OMAE2013-10025. doi:10.1115/OMAE2013-10025 (2013)

Ratnayake, R. M. C. Application of a Fuzzy Inference System for Functional Failure Risk Rank Estimation: RBM of Rotating Equipment and Instrumentation. Int. J. Loss Prevent. Proc. 29, 216-224 (2014a)

Ratnayake, R.M.C.: KBE Development for Criticality Classification of Mechanical Equipment: A Fuzzy Expert System. Int. J. Disaster Risk Reduction 9, 84-98 (2014b)

Ratnayake, R.M.C. and Markeset, T.: (2010). Maintaining Technical Integrity of Petroleum Flow Lines on Offshore Installations: A Decision Support System for Inspection Planning. In: Proceedings of the ASME 2010 29th International Conference on Ocean, Offshore and Arctic Engineering, paper no. OMAE2010-20035. doi:10.1115/OMAE2010-20035 (2010)

Ratnayake, R.M.C., Samarakoon, S.M.S.M.K., Markeset, T.: Maintenance Integrity: Managing Flange Inspections on Aging Offshore Production Facilities. In: Proceedings of the ASME 30th International Conference on Ocean, Offshore and Arctic Engineering, paper no. OMAE2011-49050, doi:10.1115/OMAE2011-49050, pp. 19-32 (2011)

Satty, T.L.: The Analytic Hierarchy Process: Planning, Priority Setting, Resource Allocation. McGraw-Hill, New York, USA (1980)

Seneviratne, A.M.N.D.B., Ratnayake, R.M.C.: In-Service Inspection of Static Mechanical Equipment: Use of a Fuzzy Inference System for Maintaining the Quality of an Inspection Program. In: Proceedings of the IEEE International Conference Industrial Engineering and Engineering Management (IEEM), Thailand (2013)

Singh, M., Markeset, T.: A Methodology for Risk-Based Inspection Planning of Oil and Gas Pipes Based on Fuzzy Logic Framework. Eng. Fail. Anal. 16, 2098-2113 (2009)

Sortrakul, N., Nachtmann, H.L., Cassady, C.R.: Genetic Algorithms for Integrated Preventive Maintenance Planning and Production Scheduling for a Single Machine. Comput. Ind. 56, $161-168$ (2005)

Straub, D., Faber, M.H.: Computational Aspects of Risk-Based Inspection Planning. ComputerAided Civil and Infrastructure Eng. 21, 179-192 (2006)

Triantaphyllou, E.: Multi-Criteria Decision Making: A Comparative Study, p. 320. Kluwer Academic Publishers, Dordrecht, The Netherlands. ISBN 0-7923-6607-7 (2000)

Valor, A., Caleyo, F., Rivas, D., Hallen, J.M.: Stochastic Approach to Pitting-CorrosionExtreme Modeling in Low-Carbon Steel. Corros. Sci. 52, 910-915 (2010)

Wang, W.: Modelling Condition Monitoring Intervals: A Hybrid of Simulation and Analytical Approaches. J. Oper. Res. Soc. 54, 273-282 (2003)

Walton, J.C., Cragnolino, G., Kalandros, S.K.: A Numerical Model of Crevice Corrosion for Passive and Active Metals. Corros. Sci. 38, 1-18 (1996)

Zio, E.: Prognostics and Health Management of Industrial Equipment. Diagnostics and Prognostics of Engineering Systems: Methods and Techniques. IGI Global (2012)

Zhang, D., Bai, X., Cai, K.: Extended Neuro-Fuzzy Models of Multilayer Perceptrons. Fuzzy Set. Syst. 142, 221-242 (2004) 